\title{
Three monkeys nearing extinction in the forest reserves of eastern Côte d'Ivoire
}

Surveys were carried out in forest reserves in eastern Côte d'Ivoire in 1997 to investigate the status of three primate taxa believed to be on the verge of extinction. The findings indicate that Procolobus badius waldroni may be extinct, and that Cercopithecus diana roloway and Cercocebus atys lunulatus may become so unless urgent action is taken.

Many primate taxa are currently threatened by hunting and loss of habitat. This is especially true in West Africa. Prompted by the IUCN/SSC's action plan for African primates (Oates, 1996), we* conducted a survey in eastern Côte d'Ivoire from 10 March to 1 May 1997 looking for evidence of three primate taxa believed to be verging on extinction (Oates et al., in press). The monkeys, whose ranges have historically extended into Côte d'Ivoire, are Cercopithecus diana roloway (Roloway monkey), Procolobus badius waldroni (Miss Waldron's red colobus) and Cercocebus atys lunulatus (whitecollared mangabey). Satellite image photographs were studied to identify forest blocks likely to harbour monkeys and four areas were selected for intensive investigation: the Bossemattie, Mabi, Yaya and Songan forest reserves (Figure 1).

To determine methods appropriate for each survey, we relied heavily on the assistance of Dr Wolf Waitkuwait of the German Gesellschaft fur Technische Zusammenarbeit (GTZ). Working in close co-operation with the Société de Dévéloppement des Forêts (SODEFOR), the GTZ co-ordinates a number of ambitious projects designed to strengthen and monitor the health of the existing forest reserves. These projects include: (i) removing

* The survey team consisted of Michael AbediLartey (Ghanaian Forestry Department), Isaac Monah (Obrachire Secondary Technical School) and the author. cocoa plantations from within reserve boundaries (Songan, Mabi); (ii) replanting primary forest trees in logged reserves (Bossemattie, Songan); (iii) creating permanent water holes for elephants (Bossemattie); and (iv) hiring former poachers to undertake regular faunal surveys within the reserves (Bossemattie, Mabi). In the course of directing these projects, the GTZ has collected reliable data on the dates and locations each monkey species was last observed. For example, a 4-year long biomonitoring programme in Bossemattie has yet to reveal evidence of Procolobus badius waldroni or Cercocebus atys lunulatus, and Cercopithecus diana roloway has been heard only once, approximately 3 years ago. This heavily logged reserve now consists of maturing secondary growth and our surveys confirmed that Bossemattie harbours only those monkey species capable of surviving in degraded forest (lesser spot-nosed guenon Cercopithecus petaurista, Campbell's monkey Cercopithecus campbelli and, possibly, white-thighed blackand-white colobus Colobus vellerosus and olive colobus Colobus verus). We learned that the situation in the Songan reserve is even more dire; official Côte d'Ivoire maps indicate that the Songan reserve consists of a relatively large block of high- canopy forest. Vehicle surveys quickly revealed that the reserve is heavily degraded with no remaining mature forest throughout. We found no areas of forest likely to contain monkeys.

Following Dr Waitkuwait's advice, we therefore concentrated our survey efforts in the interior of the least disturbed forest reserves: Mabi and Yaya. These reserves contain logged areas and small plantations on their peripheries, but pristine forest can still be found in the deeper portions. We spent 4 days and 3 nights within the Mabi reserve, accompanied by teams of former poachers employed by GTZ/SODEFOR. Starting before dawn, we conducted foot surveys along established transects as well as in areas of undisturbed forest, 


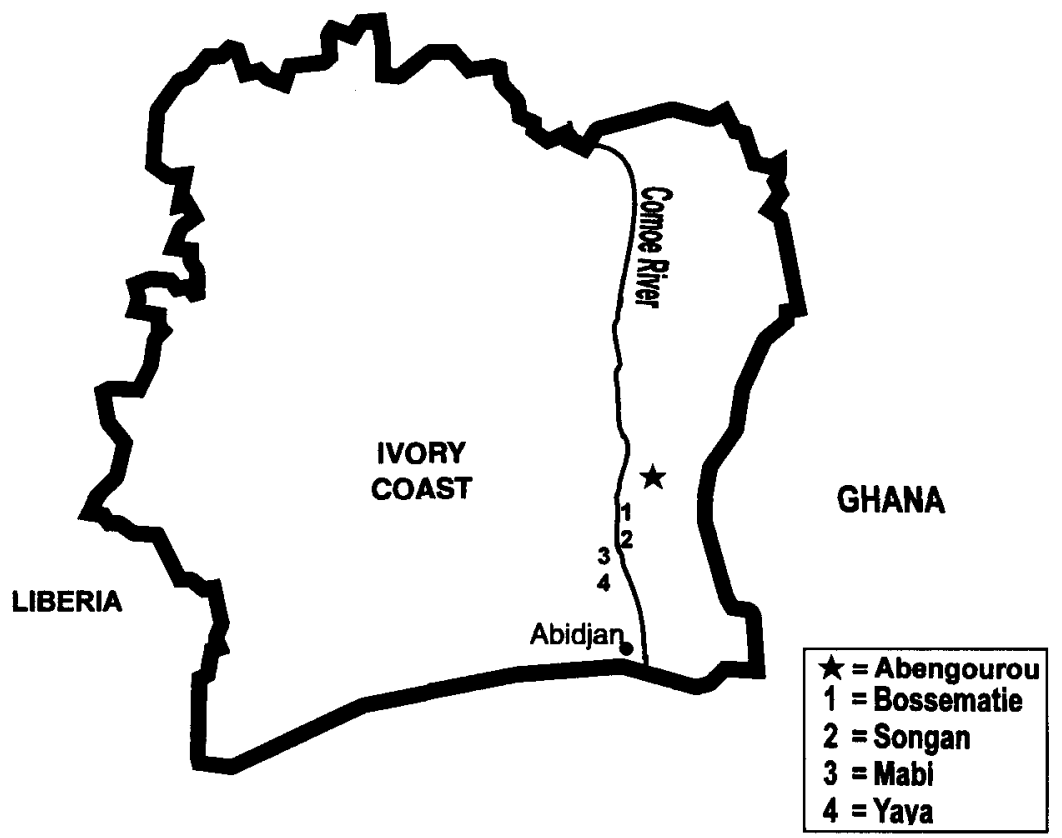

Figure 1. Location of forêts classées surveyed in this study.

listening and looking for signs of primates. No transects exist within the Yaya reserve and a bio-monitoring programme has yet to be established there. We therefore employed local hunters to guide us through the forest's interior. We spent 4 days and 3 nights surveying the deepest portions of the reserve, being careful to remain undetected by monkeys. To cover areas more efficiently and thoroughly, we typically divided our team into three groups with each instructed to walk slowly, stop frequently and note all signs of primate activity (e.g. species sighted, calls, feeding remains, etc.).

Our surveys indicate that Cercopithecus campbelli and Cercopithecus petaurista are the most abundant ${ }^{*}$ monkeys in the remaining forest of eastern Côte d'Ivoire, having been sighted and/or heard on numerous occasions in all reserves except Songan (see Table 1). Colobus vellerosus and Colobus verus are still

\footnotetext{
* Density estimates are not available because our survey methods did not meet the criteria necessary for line transect sampling (Burnham et al., 1980; Skorupa, 1987; McGraw, 1994).
}

present, but in far fewer numbers. These species were observed only once (Yaya), but data from the bio-monitoring teams suggest that both species are present in the Bossemattie and Mabi reserves (W. Waitkuwait, unpublished data). Free-ranging Roloway monkeys were encountered only once, in the Yaya reserve. We were offered a live juvenile Roloway, which was subsequently confiscated and taken to Ghana's Kumasi Zoo. Our only contact with mangabeys consisted of: (i) a smoked carcass offered for sale and (ii) photographs of a mangabey kept as a pet by a SODEFOR employee (Figure 2). No evidence of Miss Waldron's red colobus was found in any reserve or in the surrounding villages (e.g. markets, restaurants).

Although indigenous organizations such as the SODEFOR have slowed and/or stopped the destruction of rain forest in Côte d'Ivoire, they do not possess the resources necessary to combat the rising levels of hunting. This is especially true in forested areas outside the better-known national parks, the most notable being Tai and Comoe. Consequently, the 
remaining fauna enjoy little protection and poaching is rampant (e.g. Caspary, 1994); during a single 2-hour period within the Yaya reserve, we collected 31 spent shotgun shells, found six animal snares and discovered two well established poachers' camps. We heard gunshots in all reserves. For example, during the evening of 21 March as our team listened for monkeys in the Bossematie reserve, we recorded the field notes listed below:

- 18.18 hours: long call of Cercopithecus campbelli heard (direction: $218^{\circ}$ )

- 18.20 hours: shotgun heard (direction $218^{\circ}$ )

- 18.50 hours: neighbouring groups of Cercopithecus campbelli and C.petaurista heard in long call duet (group 1 direction: $173^{\circ}$, group 2 direction: $179^{\circ}$ )

- 19.02 hours: shotgun heard (direction: $172^{\circ}$ )

- 19.29 hours: shotgun heard (direction: $173^{\circ}$ )

To prevent the remaining primates in eastern Côte d'Ivoire from being eliminated, regular, systematic antipoaching patrols must be established immediately. The most effective means of achieving this goal would be to elevate the status of the most primate-rich forests (e.g. Mabi/Yaya) from forêt classée (forest reserve) to national park. Doing so would, among other things, ensure the presence (or at least the threat of presence) of armed personnel to monitor poaching activity.

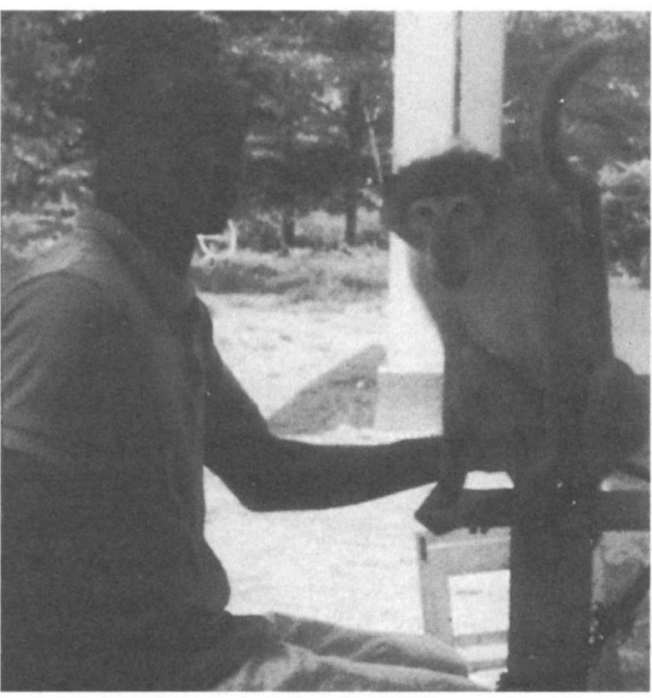

Figure 2. A white-collared mangabey Cercocebus atys lunulatus being kept as a pet in a Côte d'Ivoire village. The man in the photograph claimed to have confiscated this monkey from poachers when it was an infant. Approximately 2 months after this photograph was taken, the monkey was killed and eaten after it bit the man badly. The subspecies is severely threatened in Ghana and eastern Côte $d^{\prime}$ Ivoire and no evidence of this monkey was found in the wild. The quality of this photograph is poor (the print was obtained from the monkey's owner) but, apart from a smoked carcass, it is the only evidence collected during the survey that this subspecies still exists in Côte d'Ivoire.

Table 1. Summary of monkey surveys in the Forêts Classees in eastern Cote d'Ivoire

\begin{tabular}{|c|c|c|c|c|c|}
\hline Reserve & $\begin{array}{l}\text { Size } \\
\text { (ha) }\end{array}$ & $\begin{array}{l}\text { Survey } \\
\text { duration }\end{array}$ & $\begin{array}{l}\text { Forest } \\
\text { quality }\end{array}$ & $\begin{array}{l}\text { Species } \\
\text { confirmed }\end{array}$ & $\begin{array}{l}\text { Species } \\
\text { suspected }\end{array}$ \\
\hline Bossemattie & 18,000 & $\begin{array}{l}\text { Parts of } 6 \text { days } \\
\text { including } \\
2 \text { nights }\end{array}$ & $\begin{array}{l}\text { Maturing secondary } \\
\text { forest }\end{array}$ & $\begin{array}{l}\text { Cercopithecus petaurista } \\
\text { Cercopithecus campbelli }\end{array}$ & $\begin{array}{l}\text { Colobus vellerosus } \\
\text { Colobus verus }\end{array}$ \\
\hline Mabi & 51,000 & $\begin{array}{l}4 \text { days and } \\
3 \text { nights }\end{array}$ & $\begin{array}{l}\text { Moderately degraded } \\
\text { with areas of good } \\
\text { forest in interior }\end{array}$ & $\begin{array}{l}\text { Cercopithecus petaurista } \\
\text { Cercopithecus campbelli }\end{array}$ & $\begin{array}{l}\text { Colobus vellerosus } \\
\text { Colobus verus }\end{array}$ \\
\hline Songan & 35,000 & $\begin{array}{l}\text { Vehicle } \\
\text { surveys } 1 \text { day }\end{array}$ & $\begin{array}{l}\text { Heavily degraded } \\
\text { little remaining forest }\end{array}$ & $?$ & $?$ \\
\hline Yaya & 22,000 & $\begin{array}{l}4 \text { days and } \\
3 \text { nights }\end{array}$ & $\begin{array}{l}\text { Moderately degraded } \\
\text { with areas of good } \\
\text { forest in interior }\end{array}$ & $\begin{array}{l}\text { Cercopithecus petaurisata } \\
\text { Cercopithecus campbelli } \\
\text { Cercopithecus diana } \\
\text { Colobus vellerosus } \\
\text { Colobus verus }\end{array}$ & \\
\hline
\end{tabular}

NB. The area of forest within each reserve is considerably smaller than the size of the reserve. The number of hectares given for each reserve merely constitutes the area within the official borders of the forêt classée.

(C) $1998 \mathrm{FFI}$, Oryx, 32 (3), 233-236 


\section{SHORT COMMUNICATIONS}

At this point, the main obstacle to upgrading the reserves to national parks appears to be a general lack of interest in this area (Oates, 1996). This is unfortunate because the Côte $\mathrm{d}$ 'Ivoire government has the financial means necessary to initiate the transitional process. Further, much of the infrastructure needed to implement the transition (e.g. the GTZ/SODEFOR co-operative) is already in place. International pressure from conservation organizations would, no doubt, increase our awareness of this region's biological importance.

Readers of Oryx are regularly alerted to the continued decline of primate populations and to their dwindling habitat. This survey's results are, potentially, even more disturbing. Continuing surveys in Ghana have not so far located any surviving populations of Miss Waldron's red colobus (J. Oates, personal communication). That this monkey was also not found in our Côte d'Ivoire surveys suggests that the taxon may now be extinct. Without immediate action, the remaining primates in eastern Côte d'Ivoire await a similar fate.

\section{Acknowledgements}

Funding was provided by the Royal Zoological Society of Scotland, Conservation International, Primate Conservation Incorporated, Wildlife Conservation International and The Chicago Zoological Society. I thank the Ministere $\mathrm{d}^{\prime}$ Enseignement Supérieur et Recherche Scientifique and the directorate of the Institut d'Ecologie Tropicale for permission to carry out field work. The assistance of the Société de Dévéloppement des
Forêts (SODEFOR) and the Deutsche Gesellschaft fur Technische Zusammenarbeit (GTZ), under the direction of Dr Wolf E. Waitkuwait, proved invaluable during all aspects of the survey. John Oates and two anonymous reviewers greatly improved this manuscript.

\section{References}

Burnham, K.P., Anderson, D.R. and Laake, J.L. 1980. Estimation of density from line transect sampling of biological populations. Wildlife Monographs No. 72. The Wildlife Society, Washington DC.

Caspary, H.U. 1994. Le braconnage dans la Forêt Classée de Mabi, Côte d'Ivoire. Diploma, Institute of Geography, Humboldt University of Berlin.

McGraw, W.S. 1994. Census, habitat preference and polyspecific associations of six monkeys in the Lomako Forest, Zaire. American Journal of Primatology, 34, 295-307.

Oates, J.F. 1996. African Primates: Status Survey and Conservation Action Plan. IUCN/SSC Primate Specialist Group, IUCN, Gland, Switzerland and Cambridge, UK.

Oates, J.F., Struhsaker, T.T. and Whitesides, G.H. In press. Extinction faces Ghana's red colobus monkey and other locally endemic subspecies. Primate Conservation.

Skorupa, J. 1987. Do line-transect surveys systematically underestimate primate densities in logged forests? American Journal of Primatology, 13, 1-9.

$$
\begin{array}{r}
\text { W. Scott McGraw } \\
\text { Department of Anatomy } \\
\text { New York College of Osteopathic Medicine } \\
\text { Old Westbury, New York 11568, USA } \\
\text { E-mail: smcgraw@iris.nyit.edu }
\end{array}
$$

Received 8 September 1997

Accepted 25 March 1998 